\title{
DINASTI POLITIK PADA KEPEMIMPINAN PRESIDEN JOKOWI AKIBAT KONTESTASI POLITIK LOKAL GIBRAN-BOBBY
}

\author{
Aan Suryatwan \\ Sekolah Kajian Strategik dan Global, Universitas Indonesia \\ aansuryatwan10@gmail.comm \\ Jakarta, Indonesia
}

\begin{abstract}
After the new order, general elections (Pemilu) were directly elected by the people in the reform era. Nevertheless, the phenomenon of political dynasties did not just disappear. A ruler with the hand of his power can still do much. Although he is not the one who directly elects public positions, maintaining his power can influence the political process, including local political contestation. In this study using descriptive qualitative through the study of literature with the aim that researchers can explore the potential of President Jokowi's political dynasty. The nomination of Gibran and Bobby presented criticisms of President Jokowi's image, political ethics, and leadership. Political officials born from political dynasties usually do not perform well. That can happen to Gibran and Bobby if elected to political contestation.
\end{abstract}

Keywords: Elections; Political Dynasty; President Jokowi

\begin{abstract}
Abstrak
Pasca orde baru, pemilihan umum (pemilu) langsung dipilih oleh rakyat dalam era reformasi. Meskipun demikian fenomena dinasti politik tidak begitu saja hilang. Seorang penguasa dengan tangan kekuasaannya masih dapat berbuat banyak. Meskipun bukan dia yang memilih secara langsung jabatan-jabatan publik untuk keluarganya tapi daya kekuasaannya dapat mempengaruhi proses politik termasuk pada kontestasi politik lokal. Pada penelitian ini menggunakan deskriptif kualitatif melalui studi literatur dengan tujuan agar peneliti dapat mengeksplorasi potensi dinasti politik Presiden Jokowi. Pencalonan Gibran dann Bobby menghadirkan kritik terhadap citra, etika politik, dan kepemimpinan Presiden Jokowi. Pejabat politik yang lahir dari dinasti politik biasanya tidak memberikan kinerja yang baik. Hal tesebut dapat terjadi pada Gibran dan Bobby jika terpilih pada kontestasi politik.
\end{abstract}

Kata Kunci: Dinasti Politik; Pemilu; Presiden Jokowi

Open Access at: http://ojs.uho.ac.id/index.php/PUBLICUHO/index

Journal Publicuho is licensed under a Creative Commons Attribution 4.0 International License.

\section{PENDAHULUAN}

Keikutsertaan Bobby dan Gibran pada kontestasi politik lokal Pemilihan Kepala Daerah (Pilkada) yang menimbulkan pro dan kontra dalam kontestasi perpolitikan di Indonesia. Tentunya ini disebabkan karena keduanya merupakan keluarga presiden yang sedang menjabat yaitu Presiden Joko Widodo (Jokowi), yang mana Gibran Rakabuming Raka merupakan anak sulung Presiden Jokowi dan Bobby Nasution yang merupakan menantu presiden Jokowi. Gibran yang akan ikut serta dalam Pemilihan Walikota (Pilwalkot) Kota Solo 
(CNBC Indonesia, 2019), begitu juga halnya Bobby yang memastikan diri ikut dalam Pilwalkot Kota Medan (Detik News, 2019). Keduanya maju dalam kontestasi Pilwalkot periode 20202024 (Kompas TV, 2019).

Hal ini kemudian yang membuat pembicaraan di masyarakat tentang munculnya dinasti politik Presiden Jokowi dan merubah citra kepemimpinannya yang selama ini melekat sebagai presiden yang tidak melibatkan keluarga dalam urusan politik. Belum ada keluarga Jokowi yang terlibat atau menjadi pejabat publik yang ini dapat dilihat pada tabel berikut.

Tabel 1. Keluarga Presiden Republik Indonesia yang menjadi pejabat publik

\begin{tabular}{|c|c|c|c|c|}
\hline No. & Presiden & Tahun & Keluarga Yang Jadi Pejabat Publik & Ket. \\
\hline 1 & Soekarno & $1945-1967$ & - Megawati (Presiden Ke-5) & Anak \\
\hline \multirow{3}{*}{2} & \multirow{3}{*}{ Soeharto } & \multirow{3}{*}{ 1967-1998 } & - Mbak Tutut (Mensos 1998) & Anak \\
\hline & & & - $\quad$ Titiek Soeharto (Aleg DPR RI 2014-2018) & Anak \\
\hline & & & - $\quad$ Tommy Soeharto (Aleg DPR RI 1992-1998) & Anak \\
\hline 3 & Habibie & 1998-1999 & - & - \\
\hline 4 & Gusdur & 1999-2001 & - $\quad$ Yenni Wahid (Stafsus Presiden Gusdur) & Anak \\
\hline \multirow{2}{*}{5} & & & - $\quad$ Puan Maharani (Ketua DPR RI 2019-2024) & Anak \\
\hline & Megawati & $2001-2004$ & - $\quad$ Alm. Taufik Kiemas (MRR RI 2009-2014) & Suami \\
\hline 6 & SBY & 2004-2014 & $\begin{array}{l}\text { Edhie Baskoro (Aleg DPR RI 2014- } \\
\text { - Sekarang) }\end{array}$ & Anak \\
\hline 7 & Jokowi & 2014-sekarang & - & - \\
\hline
\end{tabular}

Pasca orde baru, pemilihan umum (pemilu) langsung dipilih oleh rakyat dalam reformasi. Meskipun demikian fenomena dinasti politik tidak begitu saja hilang. Seorang penguasa dengan tangan kekuasaannya masih dapat berbuat banyak meski bukan mereka yang memilih secara langsung jabatan-jabatan publik untuk keluarganya tapi daya kekuasaannya masih bisa berpengaruh. Ini dapat kita lihat seperti pada fenomena pemilu legislatif tahun 2009 di bawah.

Tabel 2. Kerabat Birokrat sebagai Anggota DPR dan DPD RI Periode 2009-2014

\begin{tabular}{|c|c|c|c|c|}
\hline No & Keluarga Birokrat & Hubungan Kekerabatan & $\begin{array}{l}\text { Posisi Calon } \\
\text { Legislatif }\end{array}$ & Parpol \\
\hline 1 & Presiden SBY & Anak & Anggota DPR RI & Demokra \\
\hline 2 & Presiden Megawati & Anak & Anggota DPR RI & PDIP \\
\hline 3 & Wapres Jusuf Kalla & Anak & Anggota DPR RI & Golkar \\
\hline 4 & Gub. DIY & Isteri & Anggota DPR RI & - \\
\hline 5 & Gub. Sulut & Anak & Anggota DPR RI & PDIP \\
\hline 6 & Gub. Sulsel & Anak & Anggota DPR RI & PAN \\
\hline 7 & Gub. Kaltim & Anak & Anggota DPR RI & PPP \\
\hline 8 & Gub. Kalbar & Anak & Anggota DPR RI & PDIP \\
\hline 9 & Gub. Kalsel & Anak & Anggota DPR RI & - \\
\hline 10 & Gub. Kalteng & Keponakan & Anggota DPR RI & PDIP \\
\hline 11 & Gub. Sulsel & Anak & Anggota DPR RI & GOLKAR \\
\hline 12 & Gub. Jambi & Istri & Anggota DPR RI & PAN \\
\hline
\end{tabular}


Journal Publicuho

ISSN 2621-1351 (online), ISSN 2685-0729 (print)

Volume 3 Number 3 (August-October), (2020) pp.289-300

Accredited SINTA SK.NOMOR 28/E/KPT/2019

Open Access at: http://ojs.uho.ac.id/index.php/PUBLICUHO/index DOI: 10.35817/jpu.v3i3.12972

\begin{tabular}{|c|c|c|c|c|}
\hline No & Kelvarga Birokrat & Hubungan Kekerabatan & $\begin{array}{l}\text { Posisi Calon } \\
\text { Legislatif }\end{array}$ & Parpol \\
\hline 13 & Gub. Lampung & Anak & Anggota DPR RI & - \\
\hline 14 & Gub. Banten & Anak & Anggota DPR RI & - \\
\hline
\end{tabular}

Seperti data tabel-tabel diatas, jika dibandingkan presiden-presiden sebelumnya, Presiden Jokowi termasuk yang paling low profile terkait dinasti politik. Hanya Jokowi dan Habibie yang keluarganya tidak mempunyai jabatan publik maupun menjabat di jabatan strategis lainnya. Konservatisme yang dipegang Jokowi inilah yang membuat citranya baik sebagai seorang presiden yang tidak melibatkan kelvarga dalam urusan politiknya atau anti dinasti politik.

Latar belakang yang mendasari low profile-nya Jokowi terkait dinasti politik tersebut karena dia bukan berasal dari keluarga elit atau bangsawan seperti presiden lainnya. Jika dibandingkan dengan Megawati, Presiden RI ke-5 yang merupakan anak kandung dari pendiri bangsa Soekarno, anaknya Puan Maharani juga saat ini menduduki jabatan Ketua DPR RI 2019-2024, almarhum suaminya Taufia Kiemas juga merupakan Ketua MPR RI 20092014. Selain itu ada Susilo Bambang Yudhoyono (SBY) Presiden RI ke-06 memiliki anak Agus Harimurti Yudhoyono yang mencalonkan diri dalam Pilgub DKI Jakarta, dan Edi Baskoro (IBAS) yang merupakan anggota DPR RI 2009-sekarang. IBAS menikah dengan anak dari Hatta Rajasa mantan ketua umum Partai Amanat Nasional (PAN).

Dinasti politik seperti diatas dapat membuat adanya kejenuhan politik sehingga menurunkan angka partisipasi politik. Padahal esensi dari demokrasi yaitu adanya suatu partisipasi politik karena ukuran demokrasi suatu negara dilihat dari angka partisipasi atau keterlibatan masyarakat dalam berpolitik (Ahmad, Cangara, \& Hasrullah, 2017). Orang akan muak dengan politik yang seperti ini karena kekuasaan hanya dipergilirkan untuk orangorang tertentu saja, sedang harapan dalam demokrasi semua orang mempunyai hak dan kesempatan yang sama.

Kejenuhan politik dapat terlihat dari tingkat partisipasi pemilu yang dilaksanakan. Tingkat partisipasi pemilu dalam Pilkada Serentak tahun 2018 hanya sebesar 73,24 persen pemilih. Ini berarti ada sebesar 26,76 persen masyarakat Indonesia tidak berpartisipasi dalam pemilu tersebut. Angka partisipasi tersebut diakui Komisi Pemilihan Umum (KPU) tidak mencapai target yang diinginkan yaitu sebesar 77,5 persen partisipasi pemilih (Beritagar.id, 2018). Angka non-partisipasi tersebut juga harus menjadi perhatian bersama terutama Presiden, DPR, KPU dan para stakeholder lainnya agar dapat menyelesaikan persoalan terkait partisipasi politik ini dan lebih jauh bagaimana sebaiknya mengatur persoalan dinasti politik. Apalagi dengan tidak adanya peraturan perundang-undangan yang melarang dinasti politik di Indonesia, hal ini dapat menimbulkan persoalan etika politik dan menimbulkan otoritas dalam legitimasi 
kekuasaan untuk membentuk atau mempertahankan oligarki yang ada dalam periode kekuasaan pejabat tertentu, dimana dalam topik ini adalah masa jabatan Jokowi.

\section{METODOLOGI}

Dalam penelitian ini menggunakan metode deskriptif kualitatif melalui studi literatur. Metode ini digunakan untuk menggambarkan atau mendeskripsikan secara sistematis dan akurat mengenai data-data, fakta-fakta, maupun hubungan antar fenomena yang diteliti berdasarkan data yang diperoleh dari kumpulan beberapa teori, perspektif, dan beberapa jurnal yang memiliki hubungan erat dengan topik ini. Sehingga, dengan metode ini, peneliti dapat mengeksplorasi potensi dinasti politik Presiden Jokowi (kritik, etika dan proyesi kinerja Gibran dan Bobby).

\section{HASIL DAN PEMBAHASAN}

Dinasti Politik terjadi dalam praktik politik diberbagai negara. Presiden Joko Widodo (Jokowi) memulai karir politiknya sebagai walikota solo dalam pilkada tahun 2005, kemudian terpilih kembali pada pilkada selanjutnya, kemenangan Presiden Jokowi tidak lepas dari dukungan Partai Demokrasi Indonesia Perjuangan (PDI-P). Ikut sertanya Gibran dalam pilkada walikota Kota Solo September 2020 mendatang merupakan jalur yang sama dengan yang dilakukan Jokowi dalam mengawali karir politiknya. Meskipun belum menjabat sebagai walikota solo, namun kedepan terpilihnya Gibran akan menjadi dinasti politik baru yang akan ada di Indonesia.

Banyak perspektif yang muncul dengan pencalonan Gibran dan Bobby di periode kedua pemerintahan Jokowi, meskipun berpartisipasi dalam politik tidak melanggar hak asasi, namun ada etika politik yang bisa dilanggar dengan hadirnya kedua keluarga dekat dari Presiden Jokowi. Memangku jabatan politik tidak dipungkiri sebagai jalan untuk mendapatkan legitimasi kekuasaan yang dengan begitu otoritas turut berada di genggaman. Idealnya kekuasaan politik di negara demokrasi harus berorientasi dari rakyat untuk rakyat, namun penyelewengan dan penyalahgunaan kekuasaan serta munculnya kebijakan-kebijakan politik yang hanya menguntungkan oligarki tertentu atau untuk tetap mempertahan kekuasaan partai/perorangan marak dilakukan khususnya oleh pejabatpejabat yang lahir dalam dinasti politik.

Pilihan-pilihan politik untuk mendapat kekuasaan menjadikan dinasti politik sebagai salah satu strategi yang banyak digunakan, meskipun bakat politik yang dimiliki anggota keluarga pejabat politik tidak dapat diabaikan. Dinasti politik mewariskan pengaruh politik yang dimiliki oleh Pejabat politik yang mana dalam hal ini adalah presiden Jokowi yang sedang menjabat niscaya akumulasi kekuatan dan jaringan politik yang berada dalam koalisinya diwariskan kepada pencalonan Gibran dan Bobby.

1. Dinasti Politik dan Kritiknya 
Journal Publicuho

ISSN 2621-1351 (online), ISSN 2685-0729 (print)

Volume 3 Number 3 (August-October), (2020) pp.289-300

Open Access at: http://ojs.uho.ac.id/index.php/PUBLICUHO/index

Salah satu yang keras mengkritik soal dinasti politik Presiden Jokowi ini adalah politikus Partai Demokrat Jansen Sitandaon. Jansen dalam beberapa kesempatan baik di media mainstream maupun media sosial mengkritik majunya Gibran dan Bobby di kontestasi politik. Dalam wawancara dengan TV ONE, Jansen mengutip perkataan Jokowi soal anaknya tidak suka berpolitik tiba-tiba sekarang berubah (TVOne, 2019). Ini menjadi citra ketidakkonsistenan Presiden Jokowi terhadap apa yang dia pernah katakana sebelumnya.

Selain itu muncul tudingan dinasti politik karena Gibran dan Bobby merupakan keluarga presiden yang sedang menjabat. Disisi lain minimnya rekam jejak politik Gibran dan Bobby menjadi kritik tersendiri terhadap kontestasi politik di Indonesia. Ini menambah citra buruk iklim perpolitikan di Indonesia bahwa seseorang dapat menjadi pejabat publik secara prematur hanya karena keluarga seorang penguasa politik. Hal ini juga memperpanjang riwayat dan ensiklopedia dinasti politik di negeri ini yang kemudian akan diwariskan juga kepada generasi penerus bangsa.

Dinasti politik menjadi antitesa dari tesis bahwa demokrasi adalah jalan keluar dari monarki maupun oligarki. Monarki merupakan jenis pemerintahan yang dipimpin oleh seorang penguasa (Andiyani \& Sasongkowati, 2013). Kecenderungan kekuasaan adalah membangun dinasti kekuasaan. Monarki cenderung mewariskan kekuasaannya kepada ahli warisnya dalam hal ini keluarganya. Dalam konteks ini, seorang pemimpin dapat memainkan peran dengan segala kekuasaannya untuk "mewariskan" atau memberikan kekuasaan dalam kepada anak atau keluarganya. Seperti dinasti Atut Chosiyah di Banten dan Yasin Limpo di Sulawesi Selatan, yang menghadirkan tendensi bahwa para pemain politik mentransfer kekuatan politik pada anggota keluarganya untuk membangun, mewariskan, dan mengokohkan kekuasaan serta memonopoli sistem pemilihan (Mariana \& Husin, 2017).

Demokrasi mengharuskan adanya pertanggungjawaban oleh pemimpin, terutama secara moral kepada masyarakat atau para pemilihnya, bukan kepada partai politik yang mengusungnya (Thalhah, 2009). Seorang pemimpin harus mempertanggungjawabkan moral politiknya termasuk terlibatnya keluarga dalam kontestasi politik saat dia sedang menjabat. Demokrasi merupakan suatu kehendak rakyat. Dalam Pilkada yang memutuskan untuk jadi pemimpin daerah adalah rakyat bukan kehendak presiden. Demokrasi lahir untuk membatasi kekuasaan seseorang seperti pada sistem monarki. Demokrasi menjadi autokritik untuk dinasti kekuasaan atau dinasti politik. Sehingga pada masyarakat demokrasi, jika melihat pemimpinnya yang sedang membangun dinasti politik secara otomatis dapat melakukan kritis maupun tidak memilih dinasti kekuasaan dalam suatu kontestasi politik. Sebagaimana secara historis demokrasi lahir merupakan respon dari keburukan monarki di masa-masa Yunani Kuno yang didalamnya terjadi kediktatoran. 
Sebuah dinasti politik bukan hanya karena sekadar keterlibatan seseorang atas nama background garis kekeluargaan yang kuat, tapi juga dapat dijadikan sebagai disiplin baru dalam memandang proyeksi globalisasi dan modernisasi pada wilayah politik domestik. Indonesia jika ingin menjadi pelopor dan negara percontohan dalam etika perpolitikan harus mampu memanajemen terkait dinasti politik ini sesuai dengan harapan demokrasi.

Demokrasi identik dengan konsep negara modern, sehingga banyak negara mulai menerapkan suatu proses demokratisasi menuju negara demokrasi (Nurkhalis, 2012). Negaranegara yang tadinya memegang sistem monarki berubah menjadi demokrasi termasuk Indonesia. Indonesia yang awalnya berbentuk monarki atau kerajaan-kerajaan kecil, menjadi negara demokrasi pasca kemerdekaan. Begitu juga yang terjadi di negara lain termasuk negara-negara Arab yang sangat kental dengan sistem monarki.

Tapi disisi lain negara yang mengaku dirinya modern dan demokratis, harus secara konsisten mempraktikkan penghormatan mengenai hak-hak asasi manusia yang bersifat kodrati seperti hak politik atau hak konstitusional. Ini sejalan dengan prinsip-prinsip globalisasi tentang persamaan hak dalam hidup. Demokrasi tanpa menghormati hak asasi masyarakat, tidak dapat dikatakan demokrasi tapi fasisme atau perilaku totalitarianisme yang cenderung menindas (Chaniago, 2017).

Dalam perspektif negara, negara harus mengakomodasi hak berpolitik seseorang sebagaimana ia dapat memaklumi segala hal yang terjadi dalam konteks demokrasi dan kebebasan memilih yang dimiliki oleh masyarakat selagi tidak keluar dari koridor konstitusi. Termasuk negara mengakomodasi keinginan politik Gibran dan Bobby. Masyarakat memiliki hak penuh dalam memandang politik dari berbagai sudut pandangan dikarenakan mereka mempunyai latar belakang sosial, kepentingan, serta preferensi sendiri terkait politik. Tapi dalam perspektif Jokowi sebagai presiden yang sedang menjabat, dia juga harus mengakomodasi semua kritik dan saran yang datang kepadanya utamanya terkait dinasti politik.

\section{Etika dan Regulasi}

Politik dimaknai sebagai sebuah instrumen dalam mewujudkan kepentingan dan visi pembangunan suatu negara. Instrumen ini tidaklah mampu berdiri sendiri. la harus ditopang oleh banyak komponen yang terlibat dalam proses ataupun aktivitas kenegaraan, mulai dari masyarakat sipil, organisasi massa, institusi pemerintah, bahkan komponen lain yang secara tidak langsung mempunyai daya pengaruh yang kuat. Sebutlah sistem dan pranata sosial terhadap etika yang meliputi nilai, norma, serta identitas sosial yang berlaku maupun berkembang dalam suatu negara. Etika merupakan sebuah nilai dan norma moral yang berperan menentukan perilaku hidup manusia (Awatara, 2011). 
Dalam pembahasan ini selain etika politik, etika kepemimpinan juga turut menjadi perhatian. Sebab pilihan sikap politik seorang presiden menjadi suatu etika tertentu dalam kehidupan sosial dan politik yang mana langkahnya akan menjadi kebijakan publik. Pilihan pembiaran oleh Jokowi terhadap majunya Gibran dan Bobby menjadi persoalan etika dalam kepemimpinan. Karena tidak dapat menghindari potensi persoalan dinasti politik dan nepotisme, maka kemudian hal ini sesuai dengan teori etika kepemimpinan seperti yang diuraikan kemudian.

Etika dalam kepemimpinan merupakan cara pemimpin agar dapat memimpin anggotanya sesuai kaidah, nilai, dan norma yang berlaku di masyarakat (Yanti, 2019). Jadi nilai dan norma yang berlaku serta berkembang di Indonesia sangat berpengaruh terhadap etika kepemimpinan pada tema ini. Etika memberi suatu sistem pengaturan dan prinsip yang memandu kita dalam membuat keputusan tentang apa yang benar dan salah, serta baik atau buruk dalam situasi tertentu (Northouse, 2017).

Etika Kepemimpinan adalah kepemimpinan dengan melakukan suatu tindakan normatif yang tepat melalui tindakan pribadi dan hubungan interpersonal, serta menyebarkannya kepada anggota melalui komunikasi dua arah, penguatan, dan pengambilan keputusan (Brown \& Trevino, 2006). Seorang pemimpin akan diperhadapkan pada pilihan apakah tindakannya benar atau tidak berdasarkan konsekuensi tindakan pemimpin atau pada aturan yang mengatur tindakannya, hal itu dapat ditinjau berdasarkan bidang teori etika yaitu perilaku atau karakter (Northouse, 2017).

Analisis etika kepemimpinan pada tema ini terlebih dahulu kita memisahkan analisis terhadap Presiden Jokowi dan Gibran-Bobby. Jokowi sebagai sebagai seorang pemimpin selalu menjaga sopan santun maupun etika. Hal tersebut dapat kita lihat dalam berbagai kesempatan dan berbagai media. Tapi hal ini terusik dengan tudingan dinasti politiknya yang akan dibangun. Jika memang Jokowi benar-benar ingin dicitrakan sebagai individu yang paripurna mengenai majunya putra dan menantunya di dunia politik ini akan lebih etis jika ia menunggu hingga selesai masa jabatannya sebagai presiden yaitu pada tahun 2024 . Ini dapat dilihat dari banyaknya masyarakat yang meminta Gibran agar menunggu selesainya masa jabatan ayahnya sebagai presiden (CNBC Indonesia, 2019).

Dalam sudut pandang etika kepemimpinan, Gibran dan Bobby sendiri berbeda posisinya disini dengan Jokowi. Dalam hal ini segala keputusan majunya Gibran dan Bobby dalam Pilkada adalah keputusan Gibran dan Bobby. Jokowi disini hanya sekedar dapat memberi masukan dan peringatan tapi yang memutuskan adalah Gibran dan Bobby karena itu adalah hak konstitusional mereka. Bagi Gibran dan Bobby yang jiwa mudanya terpanggil, 
yang merasa ini adalah waktunya, kalau bukan sekarang kapan lagi, tentunya jiwa itu tidak akan bisa menunggu lama melakukan lompatan-lompatan kemajuan.

Etika kepemimpinan dapat dilihat dari konsistennya ucapan seseorang karena ada kejujuran di dalamnya. Jokowi pernah mengatakan tidak akan maju dalam kontestasi pilpres karena mau memimpin Jakarta selama lima tahun. Ini pernah disampaikan Jokowi dalam janji kampanyenya dimana Jokowi pernah berjanji untuk memimpin DKI Jakarta sampai tuntas selama lima tahun (Merdeka.com, 2014). Hal ini kemudian dikritik oleh Yayat Supriyatna pengamat dari Universitas Trisakti yang menilai Jokowi tidak memiliki etika politik apabila maju sebagai capres.

Pada kenyataannya ada hal-hal yang memang harus "dilanggar" oleh seorang pemimpin untuk maslahat yang lebih besar. Ini yang kemudian menjadi alibi tersendiri untuk Jokowi seperti pada memutuskan diri untuk maju sebagai kandidat calon presiden 2014 yang lalu dan ketika membiarkan keluarganya maju dalam kontestasi politik. Begitu juga bagi Gibran dan Bobby, bahwa jika keduanya adalah keluarga Presiden Jokowi itu adalah given yang tentunya harus disyukuri dan tidak perlu dipermasalahkan. Didasarkan pada prinsip demokrasi merupakan kedaulatan rakyat yang mengandung pengertian bahwa semua manusia pada dasarnya memiliki kebebasan dan hak serta kewajiban yang sama dalam politik dan negara (Departemen Pendidikan, dan Kebudayaan, 1989). Sejalan dengan tujuan demokrasi bahwa demokrasi memperbesar kebebasan-kebebasan kemanusiaan secara konsisten untuk mencapai keputusan politik dimana individu-individu yang ingin memperoleh suatu kekuasaan diputuskan melalui cara kompetisi untuk meraih suara rakyat (Nurkhalis, 2012).

Dari perspektif fatsun politik atau kesopanan, etika dalam berpolitik majunya Gibran dan Bobby dianggap kurang etis karena Jokowi masih sementara menjabat sebagai presiden. Namun jika dilihat dari hak politik, sah-sah saja asal Gibran dan Bobby tidak memanfaatkan fasilitas negara maupun fasilitas yang melekat pada mereka. Karena hal tersebut dapat berdampak buruk apalagi jika sampai melanggar hukum. Dengan maraknya dinasti politik yang dibangun oleh pejabat-pejabat politik, hal ini mengingatkan kita kembali dengan Undang - undang No. 8 Tahun 2015 pasal 7 huruf $r$ yang seharusnya dapat digunakan kembali sebagai kontrol dalam partisipasi politik di Indonesia, agar tidak menimbulkan konflik kepentingan orang perorang/ kelompok (DPR Rl, 1999). Dimana seorang yang memiliki garis keturunan atau hubungan kekerabatan yang ingin ikut serta dalam pemilihan umum harus menunggu satu kali masa periode untuk menghindari akumulasi kekuatan politik yang tidak sehat.

Dinasti politik bila dilihat dari etika politik maka ini tidak sehat karena tidak memberi 


\section{Journal Publicuho}

ISSN 2621-1351 (online), ISSN 2685-0729 (print)

kesempatan bagi masyarakat lainnya, khususnya masyarakat biasa untuk bisa berada dalam kursi kepemimpinan. Pelanggaran etika politik dalam dinasti politik tidak hanya dilakukan oleh bakal calon pejabat politik, tetapi juga partai politik pun ikut karena akumulasi kekuatan politik dianggap memudahkan langkah mendapatkan kursi jika menggunakan kader politik yang memiliki hubungan dengan pejabat yang masih menjabat. Dinasti politik cenderung akan dimanfaatkan untuk melanggengkan kekuasaan dan mengeruk vang negara, hal ini bisa kita lihat dalam dinasti Soeharto, dan Ratu Atut di Banten (Masyitha, 2015). Disini ada semacam trauma politik terhadap dampak buruk dari dinasti politik. Tidak heran masyarakat kemudian menjadi muak dan apatis terhadap politik seperti yang digambarkan di atas akibat tingkah laku pemimpin atau stakeholder politik lainnya.

\section{Proyeksi Kinerja dan Kebijakan}

Potensi yang paling besar terjadi dari dinasti politik adalah nepotisme, dimana hal ini menjadi penyakit bagi kekuasaan dan merupakan salah satu bentuk destruktif dari dinasti politik. Manifestasinya dalam bentuk tindakan yang merugikan negara dan menguntungkan kepentingan keluarganya dan kroninya di atas kepentingan masyarakat, bangsa dan negara. Sedang dalam alam demokrasi semua perilaku politik harusnya menjadi transparan. Semua kejahatan dan keburukan akan terlihat dalam demokrasi termasuk dinasti politik maupun nepotisme. Hal ini karena dalam demokrasi wajib ada transparansi pemerintah, selain itu ada checks and balance sehingga hal itu juga yang melandasi diperkuatnya DPR sebagai lembaga pengawas pemerintah.

Adanya ketidaktransparanan pemangku kebijakan dalam menjalankan pemerintahan tidak akan dapat menciptakan pemerintahan yang baik, dalam dinasti politik kecenderungan menutupi kesalahan dan mencari keuntungan untuk kelompok tertentu dapat terjadi. Dengan demikian dinasti politik memiliki konsekuensi negatif bagi pembuatan kebijakan yang demokratis.

Terkait persoalan nepotisme, kasus majunya Gibran dan Bobby ini tidak dapat secara langsung dikategorikan nepotisme karena Gibran dan Bobby maju melalui pemilihan langsung. Jokowi tidak secara langsung mengangkat mereka sebagai Walikota. Beda halnya dengan jabatan seperti menteri dan sebagainya yang dapat dipilih langsung oleh seorang presiden sebagaimana dulu Soeharto mengangkat anaknya Mbak Tutut sebagai seorang Menteri Sosial. Walaupun mengangkat anak sendiri juga tidak dapat langsung dikatakan perbuatan nepotisme karena bukan perbuatan melawan hukum dan menyebabkan kerugian negara, tapi disini proses demokratisasi sangat penting. 
Sebagian besar dinasti politik digunakan untuk melanggengkan kekuasaan dan mencari keuntungan materi melalui jabatan politik, Apalagi pemimpin terpilih dari koalisi tertentu akan mencari untuk mengembalikan modal yang digunakan dalam partai politiknya, sehingga focus kinerja pemimpin terpilih tidak pada pelayanan publik. Dampak dinasti politik yang terjadi berbagai negara tidak jauh berbeda, seperti dampak dinasti politik yang dibuktikan dalam penelitian di Negara Brazil menyatakan bahwa hal ini, mengarah ke pemerintah yang lebih besar tanpa keuntungan yang signifikan dalam kinerja ekonomi atau penyediaan barang publik. Ekspansi pemerintah tampaknya menjadi mekanisme yang digunakan politisi dinasti untuk meningkatkan sewa dan mentransfer sumber daya ke pendukung baik melalui kontrak atau patronase pemerintah.

Hadirnya pemain politik lokal yang baru tanpa pengkaderan yang mumpuni akan menghasilkan kader politik atau pemimpin/pejabat politik yang premature, anggota dinasti politik yang terpilih karena karisma dari anggota keluarga yang menjabat atau kekuatan politiknya yang tidak dibarengi dengan keahlian dalam manajemen, membuat kebijakan dan pengambilan keputusan. Hal ini tidak akan membawa kinerja yang baik bagi sehingga melemahkan kinerja pemerintah dan kinerja ekonomi lokal.

Terdapat banyak argumen yang mengatakan keberadaan dinasti politik tidak berpengaruh terhadap pembangunan ekonomi dengan melihat pada jumlah masyarakat miskin, dan peningkatan jumlah pekerja, namun dinasti politik juga tidak memberikan kontribusi secara positif terhadap pertumbuhan ekonomi. Saat ini meskipun belum menjabat sebagai walikota Solo dan walikota Medan, Gibran dan Bobby sebagai pemain politik baru dan belum memiliki prestasi politik apapun, apalagi didukung dengan pengalaman pejabat politik yang lahir dari dinasti politik, kinerja Gibran dan Bobby dapat berujung dengan kinerja yang lemah dalam birokrasi maupun ekonomi seperti pendahulunya.

\section{KESIMPULAN}

1. Majunya Gibran dan Bobby tidak dapat dikatakan nepotisme karena tidak melanggar hukum dan merugikan negara. Jika terjadi campur tangan presiden ini menjadi preseden buruk bagi iklim dan masa depan politik Indonesia. Ini merupakan upaya pembangunan dinasti politik yang yang tidak sehat untuk masa depan perpolitikan Indonesia.

2. Banyak kritik yang terjadi diantaranya tudingan dinasti politik karena Gibran dan Bobby merupakan keluarga presiden yang sedang menjabat. Selain itu konsistensi ucapan Jokowi soal anaknya yang apatis untuk berpolitik tiba-tiba berubah pikiran. Selain itu muncul. kemudian rekam jejak politik yang minim Gibran dan Bobby menjadi kritik tersendiri terhadap kontestasi politik di Indonesia. 
3. Terlibatnya Gibran dan Bobby dalam pemilihan umum walikota Solo dan Medan di masa jabatan Presiden Jokowi tidak melanggar hak asasi dan hukum, karena pada kenyataannya tidak ada norma hukum yang membatasi terbentuknya dinasti politik di Indonesia setelah dilakukan pembatalan pada Undang-undang No.8 Tahun 2015 Pasal 7 Huruf r. Namun pada hakikatnya yang dilakukan Jokowi, Gibran dan Bobby, melanggar etika politik dan etika kepemimpinan.

4. Sebagaimana para pendahulunya dan kasus dinasti politik yang terjadi di negaranegara lain maupun di Indonesia baik ditingkat nasional maupun tingkat daerah. Gibran dan Bobby akan sulit menunjukan kinerja yang baik, dan kontribusi positif terhadap pertumbuhan ekonomi sebab fokusnya akan terpasung pada koalisi dan oligarki yang di warisi oleh Presiden Jokowi.

\section{SARAN}

1. Jika Presiden Jokowi tidak ingin citranya buruk dan dituding sedang membangun dinasti politik maka Jokowi harus mampu menahan keluarganya untuk terlibat dalam dunia politik.

2. Begitu juga untuk Gibran dan Bobby harus dapat menahan diri hingga masa jabatan Jokowi berakhir. Adapun setelah masa jabatan Jokowi berakhir mungkin interpretasi dinasti politik tidak hilang, tapi hal itu tidak akan terlalu dipermasalahkan publik karena Jokowi tidak lagi mempunyai kekuasaan seperti saat dia sedang menjabat presiden.

3. Jokowi dapat membuat momentum untuk landasan masa depan perpolitikan dengan membuat regulasi terkait dinasti politik di Indonesia. Ini sejalan dengan revolusi mental dan gebrakan-gebrakan yang ia lakukan selama menjadi pemimpin negara.

\section{DAFTAR PUSTAKA}

Ahmad, A. A., Cangara, H., \& Hasrullah. (2017). Pembatasan Kampanye Dan Rendahnya Partisipasi Pemilih Pada Pilkada Serentak 2015 Di Tiga Kabupaten Di Sulawesi Selatan. Jurnal Komunikasi Kareba, Vol.6 No.1.

Andiyani, N. K., \& Sasongkowati, R. (2013). History of the World: Sejarah Dunia Kuno dan Modern. Yogyakarta: Indoliterasi.

Awatara, I. G. (2011). Peran Etika Lingkungan dalam Memoderasi Pengaruh Kepemimpinan dan Budaya Organisasi Berwawasan Lingkungan terhadap Kinerja Karyawan Berwawasan Lingkungan. Jurnal Ekosains, Vol 3, No. 1, pp. 105-120.

Beritagar.id. (2018). Tingkat partisipasi politik Pilkada turun. Retrieved from https://beritagar.id/artikel/berita/tingkar-partisipasi-politik-pilkada-turun.

Brown, M. E., \& Trevino, L. K. (2006). Ethical leadership : A review and future directions. The Leadership Quarterly, Vol. 17(1), pp : 595-616. 
Chaniago, P. S. (2017). Demokrasi Konsensus : Kontestasi Antara Suara Voting Vs Suara Permusyawaratan. Jakarta: Voxpol Center.

CNBC Indonesia. (2019). Dulu Apolitis, Gibran Buka-bukaan Soal Maju Pilkada Solo 2020. Retrieved from https://www.cnbcindonesia.com/news/20191110213908-4-

114128 /dulu-apolitis-gibran-buka-bukaan-soal-maju-pilkada-solo-2020.

Departemen Pendidikan, dan Kebudayaan. (1989). Ensiklopedi Nasional, Jilid 4,. Jakarta: Cipta Adi Pustaka.

Detik News. (2019). Maju Pilkada, Menantu Jokowi Bobby Nasution Ingin Bangun Medan. Retrieved from https://news.detik.com/berita/d-4817767/maju-pilkada-menantujokowi-bobby-nasution-ingin-bangun-medan.

DPR RI. (1999). Undang-Undang Republik Indonesia No. 28 tahun 1999 Pasal 1 Ayat 5 Tentang Penyelenggara Negara Yang Bersih Dan Bebas Dari Korupsi, Kolusi, Dan Nepotisme.

Kompas TV. (2019). Gibran dan Bobby Maju Pilkada, Muncul Tudingan Dinasti Politik dan Nepotisme Era Baru. Retrieved from https://www.kompas.tv/article/60131/gibran-danbobby-maju-pilkada-muncul-tudingan-dinasti-politik-dan-nepotisme-era-baru.

Mariana, D., \& Husin, L. H. (2017). Democracy, local election, and political dynasty in Indonesian politics. JWP (Jurnal Wacana Politik), Vol 2 (2).

Masyitha, D. (2015). Tafsir Hermeneutika Politik Atas Gejala Demokrasi Versus Dinasti Pada Pilkada Serentak 2015. DIALOGIA: Jurnal Studi Islam dan Sosial., Vol 13, No 2 (2015).

Merdeka.com. (2014). Jokowi mau Nyapres? Ingat 31 janji ini semasa kampanye. Retrieved from https://www.merdeka.com/politik/jokowi-mau-nyapres-ingat-31-janji-ini-semasakampanye.html.

Northouse, P. G. (2017). Kepemimpinan. Jakarta: PT Indeks Permata Puri Media.

Nurkhalis. (2012). Konstruksi Demokrasi Dalam Pemikiran Nurcholish Madjid . Jurnal SosioReligia, Vol. 10, No.1.

Soebagio. (2009). Distorsi dalam Transisi Demokrasi di Indonesia. Jurnal Makara Sosial Humaniora, Vol. 13 No. 2, p. 111-116.

Thalhah, M. (2009). Teori Demokrasi Dalam Wacana Ketatanegaraan Perspektif Pemikiran Hans Kelsen. Ius Quia Iustum Law Journal, Vol.16 Doi 10.20885/iustum.vol 16.iss3.art6.

TVOne. (2019). Adu Argumen Jansen Sitindaon \& Dwi Ria Latifa Soal Kelvarga Presiden Maju Pilkada. Retrieved from https://www.youtube.com/watch?v=W3PTOltdZWg.

Yanti, N. P. (2019). Pengaruh Etika Kepemimpinan dan Tingkat Pemahaman Akuntansi Terhadap Kualitas Pelaporan Keuangan Pada PT. Raditya Dewata Perkasa. Segce : Jurnal Sains ,Akuntansi dan Manajemen, Vol. 1, No. 2. 